\title{
Turning waste into a resource: Study of the effect of containers made of giant reed weeds on the shelf life and quality of tomatoes and strawberries
}

\section{Teresa García-Ortuño 1 , Angel A. Carbonell-Barrachina ${ }^{2}$, Javier Andreu- Rodríguez ${ }^{1}$, María T. Ferrández-García ${ }^{1}$, Angel Calín-Sanchez², Manuel Ferrández-Villena ${ }^{1}$, and Clara E. Ferrández-García ${ }^{1}$}

${ }^{1}$ Departamento de Ingeniería. ${ }^{2}$ Departamento de Tecnología Agroalimentaria. Universidad Miguel Hernández de Elche, Escuela Politécnica Superior de Orihuela. Ctra. Beniel Km 3.2, 03312 Orihuela (Alicante), Spain.

\begin{abstract}
T. García-Ortuño, A.A. Carbonell-Barrachina, J. Andreu-Rodríguez, M.T. FerrándezGarcía, A. Calín-Sanchez, M. Ferrández-Villena, and C.E. Ferrández-García. 2013. Turning waste into a resource: Study of the effect of containers made of giant reed weeds on the shelf life and quality of tomatoes and strawberries. Cien. Inv. Agr. 40(1): 149-159. Giant reed (Arundo donax L.) is currently one of the greatest invasive threats to Mediterranean-type river ecosystems worldwide and can be easily transformed into a cheap and sustainable material that can be used in the manufacturing of containers for the fruit and vegetable industry. Simple trays were prepared using giant reed, and their behavior was evaluated during storage of tomatoes and strawberries. The mechanical properties of the giant reed particleboards were assayed, and it was shown that they are suitable for industrial purposes. The quality of strawberries and tomatoes stored for 7 and 14 days, respectively, in plywood (control) and giant reed containers was comparable, with no significant differences found. The parameters analyzed included weight loss, titratable acidity, total soluble solids, the maturity index, and sensory quality parameters (color, presence of decay, freshness of odor, sourness, sweetness, freshness of flavor and firmness) using a trained panel. After the shelf-life experiments, the properties of containers made with giant reed were assayed, and all of the properties met the requirements established for stacking, compression, static bending and dynamic compression. For instance, all of the containers resisted more than $5000 \mathrm{~kg}$ of compressive strain, and the maximum deflection that the containers exhibited was $3.84 \mathrm{~mm}$, which is smaller than the maximum of $6.1 \mathrm{~mm}$ allowed.
\end{abstract}

Key words: Arundo donax, invasive weed, mechanical properties, shelf-life, storage, sustainable containers.

\section{Introduction}

Giant reed (Arundo donax L.) is currently one of the greatest invasive threats to river ecosystems in Mediterranean-type climate regions worldwide

Received June 6, 2012. Accepted January 14, 2013. Corresponding author: cferrandez@umh.es
(Coffman, 2007). The Global Invasive Species Database lists giant reed among the world's 100 most invasive species (ISSG, 2012). Great efforts are being made to control and eradicate A. donax (Coffman 2007; Csurhes, 2009) but to date, the results have generally been ineffective and expensive (USDA, 2009). 
García-Ortuño et al. (2011) studied the feasibility of using giant reed particles to manufacture particleboard and obtained panels suitable for general use and for furniture manufacturing. This research demonstrated that giant reed can be easily transformed into a low-cost and sustainable material for the manufacturing of containers for the fruit and vegetable industry.

In Europe, EN standards for packaging address compliance with the requirements of the Packaging and Packaging Waste Directive (94/62/EC) (EUR-lex, 1994). The essential requirements of this directive are the following: (i) to keep packaging weight and volume to the minimum amounts necessary for the safety, hygiene and consumer acceptance of the packed product; (ii) to keep noxious and hazardous constituents to a minimum; and (iii) to ensure that packaging can be reused and/or recovered once it has been used (EUROPEN, 2009).

Giant reed particleboard, as a raw material, complies with the requirements of the Packaging and Packaging Waste Directive (94/62/EC) because it is biodegradable and renewable (Lewandowski et al., 2002; Angelini et al., 2009; Ceotto and Di Candilo, 2010; Vamvuka and Sfakiotakis, 2011). It is recoverable in the forms of recycled materials (Garcia and Freire, 2011), generated energy (Lewandowski et al., 2003; Monti et al., 2008; Angelini et al., 2009; Ceotto and Candilo, 2010; Vamvuka and Sfakiotakis, 2011), and compost (Andreu-Rodríguez et al., 2013).

Wood has traditionally been used for fruit and vegetable containers (Vigneault et al., 2009). However, solid wood has been replaced by more sustainable materials, such as plywood (for the walls) and MDF (medium-density fiberboard) panels (for the bottom), although wood is still being used for the raised corners in simple trays.

Fresh fruits and vegetables go through various processes, including handling, storage and transportation from the field to the consumer
(Vigneault et al., 2009). As quality cannot be improved after harvest, it is of great importance to minimize quality loss after harvest using the best possible harvest and post-harvest handling techniques (Kader, 2002; Prusky, 2011). The optimal design and efficiency of the forced-air cooling system (Ferrua and Singh, 2008) and appropriate design of the package are the most important factors in minimizing postharvest losses. In the last decade, modeling of transport and storage phenomena has been conducted (Verboven et al., 2006; Dehghannya et al., 2011), together with research on the effects of container openings and airflow rate (Castro et al., 2004; Castro et al., 2005; Ferrua and Singh, 2008) on the quality of fruits and vegetables.

Tomato fruit follows a climacteric ripening pattern that is controlled by ethylene (Carrari and Fernie, 2006) and involves a wide range of physical, chemical, biochemical and physiological changes. These changes occur relatively quickly after harvest, and fruits reach an over-ripe state, considered unmarketable, in a short period of time (Guillén et al., 2006). On the other hand, strawberries are highly perishable and susceptible to microbiological decay during storage, and therefore new storage technologies are required.

The objectives of the present study were to manufacture trays with giant reed particleboard with different opening configurations and to evaluate the effects of the material (compared with those of control containers of plywood) on the shelf life and quality of Spanish tomatoes and strawberries.

\section{Materials and methods}

The experimental design was carried out in three steps. First, the particleboards were constructed, and some of their mechanical properties were tested. Later, the trays were assembled, and the commodities were placed inside and stored under controlled temperature. The main quality parameters of the fruits were determined after 
harvest and during storage. Finally, the containers made of giant reed particleboard were tested according to EN standards.

\section{Raw materials}

Two giant reed (A. donax) particle sizes were used to manufacture the particleboards: (i) $0.25-1.0$ $\mathrm{mm}$ and (ii) $1.0-4.0 \mathrm{~mm}$. A mixture of $6 \%$ ureaformaldehyde class E1 and 4\% potato starch, based on the oven dry weight of the giant reed particles, was used. Ammonium nitrate at a $0.4 \%$ level (based on the weight of oven dry particles) was used as a hardener.

\section{Board manufacturing and testing}

Two types of panels (A and B) measuring $600 \mathrm{x}$ $400 \times 2.6 \mathrm{~mm}$ were manufactured in a hot press under $30 \mathrm{~kg} \mathrm{~cm}^{-2}$ of pressure at $120^{\circ} \mathrm{C}$ for $4 \mathrm{~min}$. The type A panels were made of particles passing the $1.0-\mathrm{mm}$ sieve and retained on the $0.25-\mathrm{mm}$ sieve. The type B panels were made of particles passing the $4.0-\mathrm{mm}$ sieve and retained on the $1.0-\mathrm{mm}$ sieve.

The mechanical properties tested were the modulus of rupture (MOR) and the modulus of elasticity (MOE) (CEN, 1993). The tests of the mechanical properties were conducted using an Imal universal testing machine (Model IB600, Modena, Italy).

\section{Manufacture of the containers}

Once the particleboards were manufactured, they were trimmed and cut into pieces for use in constructing containers, which consisted of simple trays measuring $300 \times 200 \times 112 \mathrm{~mm}$ (a standardized container size according to UNE 49051(AENOR 2002)). This type of container is called a "pitufo". The walls and the bottom of the package were made of giant reed particleboard pieces stapled together and adjoined to solid pine corners. These corner pieces provide the strength necessary for stacking of the trays. This type of container is mainly used for single journeys and can contain between 2.5 and $3.0 \mathrm{~kg}$ of fruit.

Twelve giant reed containers were made with the two particleboard types, with and without openings in the bottom of the container. As controls, three commercial containers of plywood were used.

\section{Plant material and experimental design}

Tomatoes (Solanum lycopersicon L., cv. Conquista) were purchased at maturity from a commercial field in Las Bayas (Elche, Alicante, Spain) and immediately transported to the Universidad Miguel Hernández (UMH) facilities in Orihuela (Alicante, Spain). Once in the laboratory, 330 fruits were selected on the basis of homogeneity of size, color and absence of defects, and batches of 10 uniform fruits were prepared at random. Thirty fruits were selected to analyze the main quality parameters at harvest (day 0 ), and the remaining 300 fruits were stored at $5^{\circ} \mathrm{C}$. Each container was sampled weekly over the course of two weeks. The experiment was repeated three times.

Strawberry fruits (Fragaria x ananassa Duch., cv. Ventana) were purchased at commercial maturity from a commercial field in Elche (Alicante, Spain) and immediately transported to the UMH facilities. Once in the laboratory, 330 fruits were selected based on homogeneity of size, color and absence of defects, and batches of 10 uniform fruit were randomly prepared. Thirty fruits were selected to analyze the main quality parameters at harvest (day 0 ), and the remaining 300 fruits were stored at $5{ }^{\circ} \mathrm{C}$, using 3 sets of five different containers with 20 fruits per container. Each container was sampled only once, after one week.

The experiment was designed according to a $2 \times 2$ factorial design plus a control treatment. The two factors were the following: i) size of the particles in the giant reed particleboard: Type A: 0.25-1.0 
mm or Type B: $1.0-4.0 \mathrm{~mm}$ and ii) openings at the bottom: yes or no.

Openings at the bottom were expected to increase the ventilation of the fruits stored and extend their shelf life.

The treatments and their abbreviations were the following: $\mathrm{CT}=\mathrm{Control}$ plywood container; $\mathrm{AC}=$ container made of giant reed particleboard type A $(0.25-1.0 \mathrm{~mm})$ with openings at the bottom; $\mathrm{AS}=$ container made of particleboard type A without openings; $\mathrm{BC}=$ container made of particleboard type $\mathrm{B}(1.0-4.0 \mathrm{~mm})$ with openings at the bottom; $\mathrm{BS}=$ container made of particleboard type B without openings.

Weight loss, titratable acidity (TA) and total soluble solids (TSS)

The weight of each fruit batch was recorded on day 0 and on the other sampling dates. Cumulative weight losses were expressed in terms of percentage of the original weight $(n=3)$. Titratable acidity (TA) [g of citric acid $\left(100 \mathrm{~g}^{-1}\right)$ ] was determined in duplicate by automatic titration (785 DMP Titrino, Methrom, Herisau, Switzerland) with $0.1 \mathrm{~mol} \mathrm{~L}^{-1}$ $\mathrm{NaOH}$ up to $\mathrm{pH} 8.1$, using $1 \mathrm{~mL}$ of diluted solution in $25 \mathrm{~mL}$ of distilled water. The concentration of total soluble solids (TSS) was determined at 20 ${ }^{\circ} \mathrm{C}$ using a digital refractometer (Atago PR-101, Atago Co. Ltd., Tokyo, Japan) and expressed in $\mathrm{g}\left(100 \mathrm{~g}^{-1}\right)$. The ratio TSS/TA was defined as the ripening index (RI).

\section{Sensory evaluation by a trained panel}

Sensory evaluation by a trained panel was used to describe the quality of the fresh tomatoes and strawberries. A panel of 8 assessors, aged 20 to 55 years (four female and four male) was trained in descriptive evaluation of fresh fruits. All the panelists work at UMH and have a wide range of expertise in sensory evaluation of foods, especially fruits and vegetables. Details about the panel selection and training can be found in Ruiz et al. (2005).

The sensory evaluation was carried out at the UMH facilities, which are equipped with individual booths and controlled illumination and temperature, over three different sessions. Samples were evaluated in triplicate. In each session, panelists tested both tomatoes and strawberries for all five treatments. The sample order for each panelist was randomized. The panelists were provided with the questionnaire and served approximately $20 \mathrm{~g}$ of fruit at $10^{\circ} \mathrm{C}$, one fruit at a time, with $5 \mathrm{~min}$ between samples. Unsalted crackers and water were provided to panelists for palate cleansing between samples.

In each questionnaire, the panelists were asked to evaluate the intensity of the following attributes: color, presence of decay, freshness of tomato or strawberry odor, sourness, sweetness, freshness of tomato or strawberry flavor and firmness. An 11-point scale was used, where zero was extremely low intensity, five was regular intensity and ten was extremely high intensity.

\section{Container testing}

To assess the ability of the containers to withstand compressive forces, stacking and compression tests were carried out following standard protocols (AENOR, 2002; AENOR, 2003; AENOR 2001). The properties tested were the static bending of the bottom of the container, static and dynamic compressive strength, and stacking strength.

The static bending test of the bottom was carried out in a bending-test device (model 50-C26/D, Controls S.L.R., Milan). The test consisted of loading a container with a certain overload and measuring the deflection after $10 \mathrm{~min}$. The load to be placed on the bottom was calculated with the following equation: 


$$
\mathrm{S}=\left(\frac{\mathrm{P}}{2}+\mathrm{P}\right)
$$

where $\mathrm{S}$ is the overload and $\mathrm{P}$ is the weight of a filled container $(\mathrm{kg})$.

The overload in this study was $4.20 \mathrm{~kg}$. This value was calculated by placing 200 -g plastic balls filled with water in the container. Three replications of the test were carried out for each type of container. The maximum deflection allowed was $2 \mathrm{~mm}$.

The second test conducted was a dynamic compression test. This test measures the maximum compressive strain that a container can resist. For this type of package, a resistance greater than $3,500 \mathrm{~kg}$ is required to meet the standards. The compression test was carried out with a fixed-platen compression tester at a speed of $10 \pm 3 \mathrm{~mm} \mathrm{~min}^{-1}$.

The stacking test consists of evaluating the strength of the package during storage under crushing loads. Two containers, one above the other, were placed on a horizontal surface and compressed in a laboratory compression testing machine (model 50-C26/D, Controls S.L.R., Milan). The method of guided loads of the UNE-EN ISO 2234:2003 (AENOR, 2003) was used. The load applied was calculated using the following equation:

$\mathrm{C}=\mathrm{M} \times(\mathrm{H}-1) \times 1.5$

where $\mathrm{M}$ is the weight of the two containers, $\mathrm{H}$ is the number of stacked containers, and 1.5 is a safety factor. The maximum deflection allowed was $5 \%$ of the total height. The load was 1,000 $\mathrm{N}$ for two stacked containers with a height of $22.3 \mathrm{~mm}$. Based on the standards, the maximum deflection was $6.1 \mathrm{~mm}$.

\section{Statistical analyses}

The data from each test were statistically analyzed. Analyses of variance (ANOVA) and $t$-tests were used to test $(\alpha=0.05)$ for significant differences among factors and levels. When the ANOVA indicated a significant difference among factors and levels, a comparison of the means was conducted using Duncan's test to identify which groups were significantly different from others at the $95 \%$ confidence level.

\section{Results and discussion}

Mechanical properties of the particleboards

The results of the MOR and MOE tests of the particleboards are given in Table 1. Both particleboards meet the standards for bending strength for general use (P1 grade) and for indoor fitment, including furniture manufacturing ( $\mathrm{P} 2$ grade), according to EN Standard 312 (CEN, 2003). The requirement for MOR for general use is $14 \mathrm{~N}$ $\mathrm{mm}^{-2}$ for a particleboard thickness of 3 to $6 \mathrm{~mm}$. For furniture manufacturing, the requirements are an MOR greater than $13 \mathrm{~N} \mathrm{~mm}^{-2}$ and an MOE greater than $1800 \mathrm{~N} \mathrm{~mm}^{-2}$ for a thickness of 3 to $4 \mathrm{~mm}$. The modulus test results indicate that both particleboards can be used to manufacture simple trays.

\section{Fruit quality parameters}

Weight losses (expressed as $\%$ of initial weight) are one of the main causes of quality losses in fruits and vegetables, due to dehydration and worsened appearance. The loss of weight in fruits is due to the action of several factors, such as temperature, humidity, and tissue characteristics, summarized by a transpiration coefficient (Thompson et al., 1998). The loss of weight in tomatoes and strawberries increased throughout the storage period, as expected (Table 2). At the end of the experiment, tomatoes stored in containers $\mathrm{AC}$ exhibited the greatest weight losses $(2.69 \%)$, followed by those in CT containers $(2.19 \%)$ and those in BC containers (2.19\%). These results suggest that the presence of holes in the containers 
Table 1. Mean values of MOR (modulus of rupture) and MOE (modulus of elasticity) of the particleboards.

\begin{tabular}{lll}
\hline Type & MOR $\left(\mathrm{N} \mathrm{mm}^{-2}\right)$ & MOE $\left(\mathrm{N} \mathrm{mm}^{-2}\right)$ \\
\hline $\mathrm{A}^{1}$ & 26.01 & 3246.82 \\
$\mathrm{~B}^{1}$ & 17.10 & 1965.90 \\
Requirements $^{2}$ & 14.00 & $\mathrm{~N} / \mathrm{A}$ \\
Requirements $^{\mathrm{f}}$ & 13.00 & 1800.00 \\
\hline
\end{tabular}

${ }^{1}$ Giant reed particleboard A: $0.25-1.0 \mathrm{~mm}$ and B: $1.0-4.0 \mathrm{~mm} .{ }^{2}$ For general uses according to the EN 312 (CEN, 2003) standard. "For interior-grade type (including furniture), according to the EN 312 (CEN, 2003) standard.

induced greater weight losses, perhaps due to greater contact of the plant material with the air, among other reasons. A similar trend was observed for strawberries (Table 2); however, statistically significant differences between CT and AS containers were not detected.

Organic acids and sugars, expressed as titratable acidity (TA) and total soluble solids (TSS), respectively, are correlated to fruit flavor (Ferguson et al., 2003). Fruit flavor, firmness and aroma profile are the main fruit attributes that contribute to consumer acceptance (Crisosto et al., 2004). TA decreased during storage in both tomatoes and strawberries as the ripening process advanced. A similar trend has been observed by other researchers for tomatoes (Guillén et al., 2006) and strawberries (Aday et al., 2011). At the end of the storage period, the TA of the tomatoes stored in AS was significantly higher than those of fruits

Table 2. Weight loss (\%) of tomatoes and strawberries during 14 days of storage.

\begin{tabular}{lllll}
\hline & \multicolumn{3}{c}{ Weight loss (\%) } \\
\cline { 2 - 4 } Containers $^{1}$ & Day 7 & Day 14 & Total & Strawberries \\
\cline { 2 - 4 } CT & $0.97 \pm 0.06 \mathrm{~b}^{\uparrow}$ & $1.22 \pm 0.06 \mathrm{~b}$ & $2.19 \pm 0.06 \mathrm{~b}$ & $7.26 \pm 0.2 \mathrm{~b}$ \\
$\mathrm{AC}$ & $1.51 \pm 0.07 \mathrm{a}$ & $1.18 \pm 0.04 \mathrm{~b}$ & $2.69 \pm 0.05 \mathrm{a}$ & $8.21 \pm 0.2 \mathrm{a}$ \\
$\mathrm{AS}$ & $0.67 \pm 0.03 \mathrm{~d}$ & $1.05 \pm 0.08 \mathrm{c}$ & $1.72 \pm 0.05 \mathrm{c}$ & $7.57 \pm 0.4 \mathrm{~b}$ \\
$\mathrm{BC}$ & $0.81 \pm 0.05 \mathrm{c}$ & $1.38 \pm 0.04 \mathrm{a}$ & $2.19 \pm 0.05 \mathrm{~b}$ & $8.14 \pm 0.3 \mathrm{a}$ \\
BS & $0.83 \pm 0.05 \mathrm{c}$ & $0.99 \pm 0.05 \mathrm{c}$ & $1.82 \pm 0.05 \mathrm{c}$ & $6.53 \pm 0.3 \mathrm{c}$ \\
ANOVA $^{2}$ & $* * *$ & $* * *$ & $* * *$ & $* * *$ \\
\hline
\end{tabular}

${ }^{1}$ Treatments: $\mathrm{CT}=\mathrm{Control}$ plywood container; $\mathrm{AC}=$ container made of giant reed particleboard type $\mathrm{A}$ $(0.25-1.0 \mathrm{~mm})$ with openings at the bottom; $\mathrm{AS}=$ container made of particleboard type A without openings; $\mathrm{BC}=$ container made of particleboard type $\mathrm{B}(1.0-4.0 \mathrm{~mm})$ with openings at the bottom; $\mathrm{BS}=$ container made of particleboard type B without openings. ${ }^{2}$ Significant $\mathrm{F}$ ratio at $\mathrm{P} \leq 0.001$. Treatment means of the ANOVA test (values are the mean values of 3 replications \pm standard error; values followed by the same letter within the same column were not significantly different).

stored in all other container types (Figure 1). All of the strawberries monitored exhibited similar TA values, regardless of the treatment/container $\left(0.60 \mathrm{~g}_{\text {citric }}\right.$ acid $\left.100 \mathrm{~g}^{-1}\right)$. In contrast to the TA, the TSS of both the tomatoes and the strawberries increased during storage. The control tomatoes
(CT) had the highest TSS contents, followed by $\mathrm{AS}>\mathrm{BS}>\mathrm{AC}>\mathrm{BC}$, with significant differences among treatments (Figure 2). The strawberries stored in AC and BS had higher values of TSS than the strawberries stored in the other types of containers (Figure 3). 


\section{Descriptive sensory analysis}

The initial conditions (day 0) of the tomatoes were characterized by a high tomato aroma (9.0) and low sourness and sweetness intensities (4.0 and 3.0, respectively). The color was uniform and had an

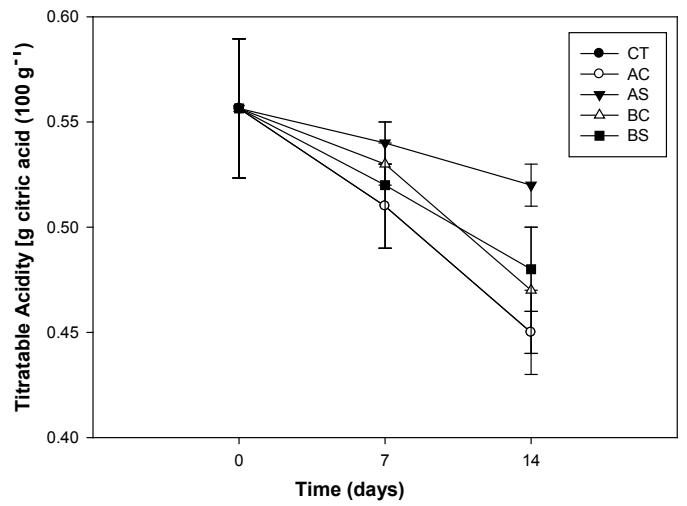

Figure 1. Change in the titratable acidity (TA) of tomatoes stored for 14 days. CT=control plywood container; $\mathrm{AC}=$ container made of giant reed particleboard type $\mathrm{A}$ $(0.25-1.0 \mathrm{~mm})$ with openings at the bottom; $\mathrm{AS}=$ container made of particleboard type $\mathrm{A}$ without openings; $\mathrm{BC}=$ container made of particleboard type $\mathrm{B}(1.0-4.0$ $\mathrm{mm}$ ) with openings at the bottom; $\mathrm{BS}=$ container made of particleboard type B without openings. intensity of approximately 7.0. All of the samples were free of decay ( 0 ) and retained high firmness (9.0) throughout the duration of the experiment. The final conditions were affected by both storage and container type. The tomatoes stored in $\mathrm{AC}$ containers had lower values of firmness (5.0),

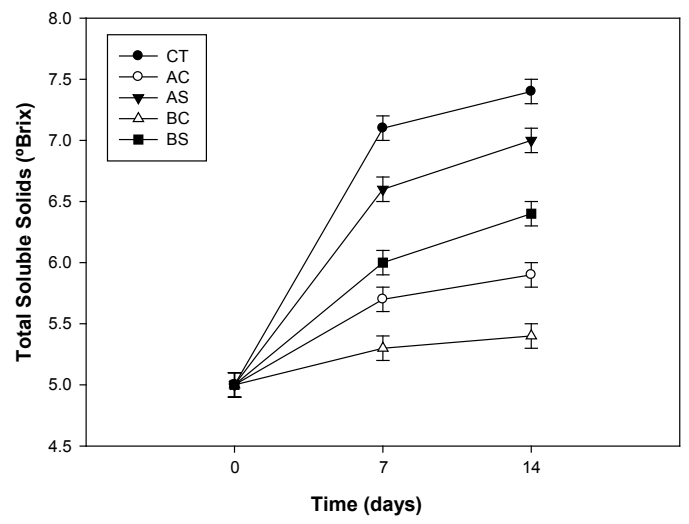

Figure 2. Change in the total soluble solids (TSS) in tomatoes stored for 14 days. $\mathrm{CT}=$ control plywood container; $\mathrm{AC}=$ container made of giant reed particleboard type A $(0.25-1.0 \mathrm{~mm})$ with openings at the bottom; $\mathrm{AS}=$ container made of particleboard type $\mathrm{A}$ without openings; $\mathrm{BC}=$ container made of particleboard type $\mathrm{B}$ $(1.0-4.0 \mathrm{~mm})$ with openings at the bottom; $\mathrm{BS}=$ container made of particleboard type $\mathrm{B}$ without openings.

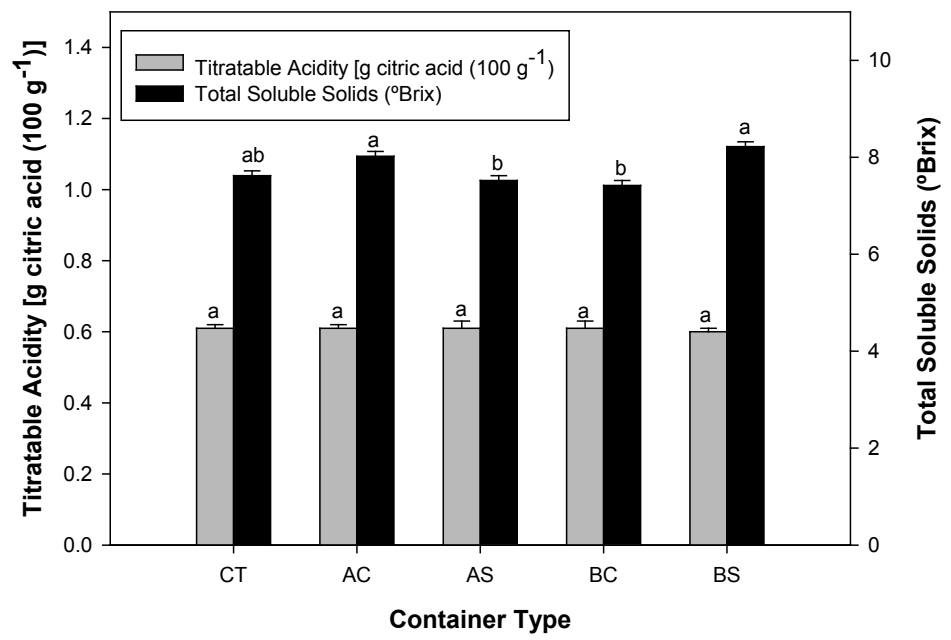

Figure 3. Titratable acidity (TA) and total soluble solids (TSS) of strawberries at the end of the storage period. $\mathrm{CT}=$ control plywood container; $\mathrm{AC}=$ container made of giant reed particleboard type A $(0.25-1.0 \mathrm{~mm})$ with openings at the bottom; $\mathrm{AS}=$ container made of particleboard type $\mathrm{A}$ without openings; $\mathrm{BC}=$ container made of particleboard type $\mathrm{B}(1.0-4.0 \mathrm{~mm})$ with openings at the bottom; $\mathrm{BS}=$ container made of particleboard type $\mathrm{B}$ without openings. 
most likely related to their great weight loss. The tomatoes stored in CT and AS containers were sweeter than the fruits corresponding to the rest of the treatments (6.0 and 5.5, compared to a mean value of 4.0 , respectively), while the intensity of the tomato sourness for the CT and AS treatments was lower than in tomatoes stored in other containers (mean of 4.0) but similar to the score at day 0 (3.0). Color was not significantly affected by the container type used for storage, but the color intensity was affected by storage, with tomatoes having a more intense red color at the end of the storage period (mean of 8.5 at day 14 , compared to 7.0 at day 0 ), as expected. However, the intensity of the tomato aroma was constant throughout the experiment (mean of 9.0).

The initial conditions of the strawberries were characterized by a high strawberry aroma (9.0), low sourness (4.0) and relatively high sweetness (6.0). At day 0, the strawberries exhibited no decay, elevated color intensity (8.0) and high firmness (7.0), implying that only high-quality strawberries were used in this experiment. At the end of the storage period ( 7 days), the fruit quality was similar in all fruits except in the case of fruit appearance (some dehydration symptoms were visible in some fruits). Strawberries stored in containers $\mathrm{AC}$ and $\mathrm{BC}$ had notable decay intensities (5.0 and 5.5, respectively), which could be related to their notable weight losses.

\section{Container properties}

The results of the tests performed are shown in Table 3. Control containers (CT) were not tested because they are already commercialized and therefore they achieve the requirements of the standards.

All of the container types met the requirements of the static bending test. The AC containers exhibited the largest deflections at the bottom, while the BS containers exhibited the smallest deflections, although no statistically significant differences were found between containers AC and $\mathrm{BC}$, both with openings at the bottom, or among $\mathrm{AS}, \mathrm{BC}$, and $\mathrm{BS}$.

All of the container types met the requirements of the dynamic compression test, resisting more than $5,000 \mathrm{~kg}$ under compressive strain. Statistically insignificant differences existed among the container types, meaning that this property does not depend on either the particle size or the presence of holes at the bottom of the tray.

The last test performed was the stacking test. The maximum deflection allowed for a height of $22.3 \mathrm{~mm}$ (two stacked containers) was $6.1 \mathrm{~mm}$. All the containers passed this test, exhibiting a maximum deflection of $3.84 \mathrm{~mm}$ (container BC), with no significant differences among the container

Table 3. Results of the compression and stacking tests performed.

\begin{tabular}{|c|c|c|c|c|}
\hline Containers $^{1}$ & Weight (kg) & $\begin{array}{l}\text { Deflection of the bottom } \\
\qquad(\mathrm{mm})\end{array}$ & $\begin{array}{l}\text { Deflection compression } \\
\text { static loads }(\mathrm{mm})\end{array}$ & $\begin{array}{l}\text { Dynamic compression } \\
\qquad(\mathrm{kg})\end{array}$ \\
\hline $\mathrm{AC}$ & $353.00 \pm 3.61 \mathrm{c}^{\pi}$ & $0.363 \pm 0.051 \mathrm{a}$ & $3.610 \pm 0.017 \mathrm{a}$ & $5623 \pm 986 a$ \\
\hline AS & $374.33 \pm 1.15 b$ & $0.257 \pm 0.021 b$ & $3.843 \pm 0.116 \mathrm{a}$ & $5653 \pm 766 a$ \\
\hline $\mathrm{BC}$ & $349.33 \pm 1.15 \mathrm{c}$ & $0.273 \pm 0.076 \mathrm{ab}$ & $3.823 \pm 0.165 \mathrm{a}$ & $5423 \pm 529 a$ \\
\hline BS & $387.67 \pm 1.15 \mathrm{a}$ & $0.207 \pm 0.021 b$ & $3.680 \pm 0.104 \mathrm{a}$ & $5217 \pm 459 \mathrm{a}$ \\
\hline ANOVA $^{2}$ & $* * *$ & $* * *$ & N.S. & N.S. \\
\hline EN Standards & N.A. ${ }^{3}$ & $\leq 2$ & $\leq 6.1$ & $\geq 3500$ \\
\hline
\end{tabular}

${ }^{1}$ Treatments: $\mathrm{AC}=$ container made of giant reed particleboard type $\mathrm{A}(0.25-1.0 \mathrm{~mm})$ with openings at the bottom; $\mathrm{AS}=$ container made of particleboard type A without openings; $\mathrm{BC}=$ container made of particleboard type $\mathrm{B}(1.0-4.0$ $\mathrm{mm}$ ) with openings at the bottom; $\mathrm{BS}=$ container made of particleboard type B without openings. ${ }^{2} \mathrm{~N}$.S.: the F ratio is not

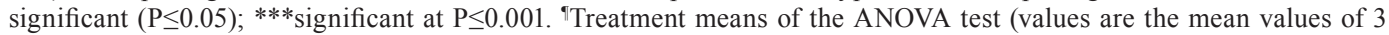
replications \pm standard error; values followed by the same letter within the same column were not significantly different). ${ }^{3}$ N.A. $=$ not applicable. 
types. This means that the particle size of the particleboards and the presence of holes did not affect the behavior of the containers in this test.

In summary, the results of this study suggest that giant reed particleboards can be used to manufacture simple trays that can be used to contain and store fruits such as tomatoes and strawberries. The physico-chemical and sensory properties/attributes of tomatoes and strawberries stored in such containers were comparable to those of tomatoes and strawberries stored in control containers made of plywood. The results of these postharvest studies demonstrate that giant reed containers can be used in the storage, transport, distribution and marketing of vegetables and fruits without any negative effects on the shelf life or quality of foods and with the advantages of sustainability and respect for the environment.

\section{Acknowledgments}

The authors would like to thank the Ministerio de Economía y Competitividad of Spain for its financial support of the project (MINECO, ref BIA 2009-11605).

\section{Resumen}

T. García-Ortuño, A.A. Carbonell-Barrachina, J. Andreu-Rodríguez, M.T. FerrándezGarcía, A. Calín-Sanchez, M. Ferrández-Villena, C.E. Ferrández-García. 2013. Convirtiendo residuos en recursos: Estudio del efecto de envases de caña común en la vida útil y la calidad de tomates y fresas. Cien. Inv. Agr. 40(1):149-159. La caña común (Arundo donax L.) es en la actualidad una de las plantas invasoras más agresiva en los ecosistemas de los ríos en las regiones de clima mediterráneo en todo el mundo. Esta planta se puede utilizar como material barato y sostenible para la fabricación de envases de fruta y verdura. Se hicieron envases con tableros de partículas de caña común y se evaluó su comportamiento durante el almacenaje refrigerado de tomates y fresas. Se determinaron las propiedades mecánicas de los tableros y se comprobó que cumplían los requisitos para su uso industrial. Se evaluó la calidad de las fresas y los tomates tras 7 y 14 días de almacenamiento, obteniendo resultados comparables sin diferencias significativas entre envases control de contrachapado y los envases de caña común. Los parámetros analizados fueron pérdida de peso, acidez valorable, sólidos solubles totales, índice de madurez, y calidad sensorial (color, presencia de podredumbre, olor a fruta fresca, acidez, dulzor, sabor a fruta fresca y firmeza). Posteriormente, tras los estudios de vida útil, se determinaron las propiedades de los envases. Todos cumplieron los requisitos establecidos de apilado, compresión, y fuerza estática y dinámica. Por ejemplo, los contenedores resistieron más de $5.000 \mathrm{~kg}$ sometidos a compresión y la deflexión máxima del fondo fue de $3,84 \mathrm{~mm}$, siendo el máximo permitido $6,10 \mathrm{~mm}$.

Palabras clave: Almacenaje, Arundo donax, envases sostenibles, mala hierba invasora, propiedades mecánicas, vida útil. 


\section{References}

Aday, M.S., C. Caner, and F. Rahvali. 2011. Effect of oxygen and carbon dioxide absorbers on strawberry quality. Postharvest Biology and Technology 62:179-187.

AENOR. 2002. UNE 49051. Packaging. Wood packaging for fruits and vegetables. Base of $300 \mathrm{~mm}$ x $200 \mathrm{~mm}$. Asociación Española de Normalización y Certificación (AENOR). Madrid, Spain. 12 pp.

AENOR. 2002. UNE 49706. Packaging. Packaging for the transport of fruits and vegetables. Determination of the static deflection of the bottom. Asociación Española de Normalización y Certificación (AENOR). Madrid, Spain. 6 pp.

AENOR. 2001. UNE-EN ISO 12048. Packaging. Complete, filled transport packages. Compression and stacking test using a compression tester. Asociación Española de Normalización y Certificación (AENOR). Madrid, Spain. 13 pp.

AENOR. 2003. UNE-EN ISO 2234. Packaging. Complete, filled transport packages and unit loads. Stacking test using a static load. Asociación Española de Normalización y Certificación (AENOR). Madrid, Spain. 11 pp.

Andreu-Rodríguez, J., E. Medina, M.T. FerrándezGarcía, M. Ferrández-Villena, C.E.FerrándezGarcía, C. Paredes, M.A. Bustamante, and J. Moreno-Caselles. 2013. Agricultural and industrial valorisation of Arundo donax L. Communications in Soil Science and Plant Analysis 44(1-4):598-609.

Angelini, L.G., L. Ceccarini, N. Nassi, and E. Bonari. 2009. Comparison of Arundo donax L. and Miscanthus x giganteus in a long-term field experiment in Central Italy: Analysis of productive characteristics and energy balance. Biomass and Bioenergy 33:635-643.

Carrari, F., and A.R. Fernie. 2006. Metabolic regulation underlying tomato fruit development. Journal of Experimental Botany 57:1883-1897.

Castro, L.R., C. Vigneault, and L.A.B. Cortez. 2005. Effect of container openings and airflow rate on energy required for forced-air cooling of horticultural produce. Canadian Biosystems Engineering 47:3.1-3.9.

Castro, L.R., C. Vigneault, and L.A.B. Cortez. 2004. Container opening design for horticultural produce cooling efficiency. International Journal of Food, Agriculture and Environment 2:135-140.

Ceotto, E., and M. Di Candilo. 2010. Shoot cuttings propagation of giant reed (Arundo donax L.) in water and moist soil: The path forward? Biomass and Bioenergy 34:1614-1623.

Crisosto, C.H., D. Garner, G.M. Crisosto, and E. Bowerman. 2004. Increasing "Blackamber" plum (Prunus salicina Lindell.) consumer acceptance. Postharvest Biology and Technology 34:237-244.

Coffman, G.C. 2007. Factors Influencing Invasion of Giant Reed (Arundo donax). In: Riparian Ecosystems of Mediterranean-type Climate Regions. Doctoral Thesis. Environmental Health Sciences. University of California. Los Angeles, California, USA. 282 pp.

Csurhes, S. 2009. Weed risk assessment. Giant reed. Arundo donax. Queensland Primary Industries and Fisheries. Department of Employment, Economic Development and Innovation. Queensland, Australia. Available online at: www.daff.qld.gov. au/documents/Biosecurity_EnvironmentalPests/ IPA-Giant-Reed-Risk-Assessment.pdf (Website accessed: May 20, 2012).

Dehghannya, J., M. Ngadi, and C. Vigneault. 2011. Mathematical modelling of airflow and heat transfer during forced convection cooling of produce considering various package vent areas. Food Control 22:1393-1399.

EUR-lex, 1994. Directive 94/62/EC of 20 December 1994 on packaging and packaging waste. Brussels: European Parliament and Council. Available online at: http://eurlex.europa.eu/LexUriServ/LexUriServ. do?uri=CELEX:31994L0062:EN:NOT (Website accessed: May 6, 2012).

CEN. 1993. EN 310, 1993. Wood-based panels. Determination of modulus of elasticity in bending and of bending strength. European Committee for Standardization (CEN). Brussels, Belgium. 12 pp. EUROPEN. 2009. Packaging in the Sustainability Agenda: A Guide for Corporate Decision Makers. 
Brussels. European Organization for Packaging and the Environment (EUROPEN). Available online at: www.europen.be (Website accessed: May 6, 2012).

Ferguson, I.B., L.M. Boyd, and A.M. Barnett. 2003. Fruiting position, mineral concentration and incidence of physiological pitting in "Hayward" kiwifruit. Journal of Horticultural Science and Biotechnology 78:505-511.

Ferrua, M.J., and R.P. Singh. 2008. A nonintrusive flow measurement technique to validate the simulated laminar fluid flow in a packed container with vented walls. International Journal of Refrigeration 31:242-255.

Garcia, R., and F. Freire. 2011. Comparative assessment of environmental life-cyclebased tools: an application to particleboard. International Symposium on Sustainable Systems and Technology (IEEE-ISSST). May 16-18, 2011, Chicago, Illinois, USA. DOI: 10.1109/ ISSST.2011.5936915.

García-Ortuño, T., J. Andreu-Rodríguez, M.T. Ferrández-García, M. Ferrández-Villena, and C.E. Ferrández-García. 2011. Evaluation of the physical and mechanical properties of particleboard made from giant reed (Arundo donax L.). Bioresources 6:477-486.

Guillén, F., S. Castillo, P.J. Zapata, D. MartínezRomero, M. Serrano, and D. Valero. 2006. Efficacy of 1-MCP treatment in tomato fruit. 2. Effect of cultivar and ripening stage at harvest. Postharvest Biology and Technology 42:235-242.

ISSG. 2012. Arundo donax (grass). Global Invasive Species Database, Invasive Species Specialist Group (ISSG) of the Species Survival Commission of the IUCN-World Conservation Union. Available online at: www.issg.org/database/species/ecology. asp? $\mathrm{si}=112 \& \mathrm{fr}=1 \& \mathrm{sts}=\&$ lang $=\mathrm{EN} \quad$ (Website accessed: June 4, 2012).

Kader, A.A. 2002. Postharvest Technology of Horticultural Crops. Publ. no. 3311, $3^{\text {rd }}$ ed. Coop. Ext. Uni. Of Ca. Davis (CA). 535 pp.

Lewandowski, I., J.M.O. Scurlock, E. Lindvall, and M. Christou. 2003. The development and current status of perennial rhizomatous grasses as energy crops in the US and Europe. Biomass and Bioenergy 25:335-361.

Monti, A., N. Di Virgilio, and G. Venturi. 2008. Mineral composition and ash content of six major energy crops. Biomass and Bioenergy 32:216-223.

Prusky, D. 2011. Reduction of the incidence of postharvest quality losses, and future prospects. Food Security 3:463-474.

Ruiz, J.J., L. Cuenca, S. García-Martínez, and A.A. Carbonell-Barrachina. 2005. Reclutamiento, entrenamiento y validación de un panel de catadores especializado en tomate en fresco. Agrícola Vergel 286:475-485.

Thompson, J.F., F.G. Mitchell, T.R. Rumsey, R.F. Kasmire, and C.H. Crisosto. 1998. Commercial cooling of fruits, vegetables, and flowers. In: J.F. Thompson, F.G. Mitchell, T.R. Rumsey, R.F. Kasmire, and C.H. Crisosto (eds.). Oakland, California: University of California. Division of Agriculture and Natural Resources. Publ. no. $21567.61 \mathrm{pp}$

USDA. 2008. Field Release of the Arundo Wasp, Tetramesa romana \{Hymenoptera: Eurytomidae\}, an Insect for Biological Control of Arundo donax \{Poaceae\}, in the Continental United States Environmental Assessment October 2008. Available online at: www.regulations.gov/ fdmspublic/component/main?main=DocketDetai $1 \& \mathrm{~d}=$ APHIS-2008-0141 (Website accessed: May 30, 2012).

Vamvuka, D., and S. Sfakiotakis. 2011. Effects of heating rate and water leaching of perennial energy crops on pyrolysis characteristics and kinetics. Renewable Energy 36:2433-2439.

Verboven, P., D. Flick, B.M. Nicolai, and G. Alvarez. 2006. Modelling transport phenomena in refrigerated food bulks, packages and stacks: basics and advances. International Journal of Refrigeration 29:985-997.

Vigneault, C., J. Thompson, and S. Wu. 2009. Designing container for handling fresh horticultural produce. Postharvest Technologies for Horticultural Crops 2:25-47. 
